\title{
放射線誘起表面活性を利用した防食*
}

\author{
古 谷 正 裕 ${ }^{* 1}$ 賞 雅 寛 而 $^{* 2}$ 岡 本 孝 司*3 \\ 安 永 龍 哉*4 植 松 進*5
}

\section{Corrosion Control Based on Radiation Induced Surface Activation}

\author{
Masahiro FURUYA, Tomoji TAKAMASA, Koji OKAMOTO, \\ David T. YASUNAGA and Susumu UEMATSU
}

\begin{abstract}
When a semiconductor film is irradiated by gamma rays, excited electrons are transferred to a base metal in contact with the film, resulting in a drop of corrosion potential. The authors propose a corrosion mitigation method based on radiation induced surface activation (RISA) phenomena by supplying gamma rays from outside the material, or based on a self-excited methodology activating the film and/or the base metal. The corrosion potential of $\mathrm{ZrO}_{2}$ coated SUS304L was shifted down to the range between $-90 \mathrm{mV}$ and $-300 \mathrm{mV} v s$. SSE by gamma-ray irradiation. The corrosion potential was further shifted down to $-600 \mathrm{mV}$ when a CoCr intermediate layer was inserted between the $\mathrm{ZrO}_{2}$ spray coating film and the SUS304L base metal. Iron specimens with a spray coating film of $\mathrm{TiO}_{2}$, $\mathrm{ZrO}_{2}$, and $\mathrm{Al}_{2} \mathrm{O}_{3}$ were immersed in a $3 \mathrm{wt} \%$ sodium chloride aqueous solution. Pitting and general corrosion were observed on both the specimens kept in a darkroom and illuminated with ultraviolet rays. Pitting and general corrosion were, however, suppressed on all three specimens irradiated with gamma rays.
\end{abstract}

\section{1. 緒言}

20 世紀初頭のステンレス鋼の発見以来、金属材料 に光が照射された場合、非照射の場合と比較して腐食 量が小さくなることは経験的に知られていた。最近の 研究により、この光照射と不動態皮膜の関係が解明さ れつつあり、ステンレス鋼の表面で数 $\mathrm{nm}$ の厚さをも つ不動態皮膜は、半導体的性質を有し、光照射により 改質されることが分かってきた。柴田 ${ }^{1)}$ 、藤本ら ${ }^{2)-5 \text { )、 }}$ および杉本6),7) は、不動態皮膜は禁止帯幅 2 $4 \mathrm{eV}$ の 酸化物半導体とみなすことができ、光照射により皮膜 中の $\mathrm{Cr}$ 濃度上昇が起こり、 $\mathrm{n}$ 型半導体として振舞い、 ステンレス鋼の耐食性が向上すると報告している。

一方、妹川 ( $^{8)} 、$ Akashi et al. ${ }^{9)}$ 、Fukuya et al. ${ }^{10)}$ はス テンレス鋼の表面にこの半導体的性質をもつ皮膜を設 け、紫外線等の光を照射することにより応力腐食割れ (SCC) を抑制することを報告している。この作用を利 用して船舶・海洋構造物の損傷・腐食損傷を防止する ことができれば、船舶・海洋構造物の使用保全の運転

\footnotetext{
* 原稿受付 2005 年 3 月 23 日

*1 財団法人 電力中央研究所

*2 正員 東京海洋大学 海洋工学部海洋電子機械工学科

*3 東京大学大学院工学研究科 システム量子工学専攻

$* 4$ 株式会社 神戸製鋼所

*5 独立行政法人 海上技術安全研究所
}

効率は著しく改善される。しかしながら、船舶・海洋 構造物で用いられているプラント配管・プラント構造 物外板（特に海水中構造部）への均一な紫外線照射が 困難である。

筆者らは、自然生成された不動態皮膜ではなく、半 導体特性を有する酸化ジルコニウムなどの溶射皮膜を 設けた金属に $y$ 線照射すると、腐食電位を卑化させて 耐食性が向上することを発見した ${ }^{11)}$ 。同様に、親水化

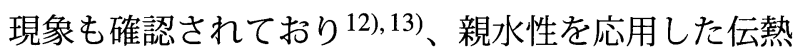
向上技術の研究も進められている14)。放射線が物質に 照射され、これらの機能を発現する現象を放射線誘起 表面活性 (RISA: Radiation Induced Surface Activation) 現象と呼んでいる。

本研究の目的は、この RISA 効果を利用した防食技 術に関して、酸化物被膜に放射線を照射し、母材の耐 食性を把握する試験を行い、基礎的な知見を得ること である。

\section{RISA 効果を利用した防食技術}

RISA 効果を利用した防食機構は現在解明中である が、今までに得られた幾つかの知見から次のように考 えることができる。母材（例えば、ステンレス鋼）の 表面に RISA効果を発現する皮膜を設けることにより (Fig.1 参照)、溶液と接する皮膜の電子エネルギー状 


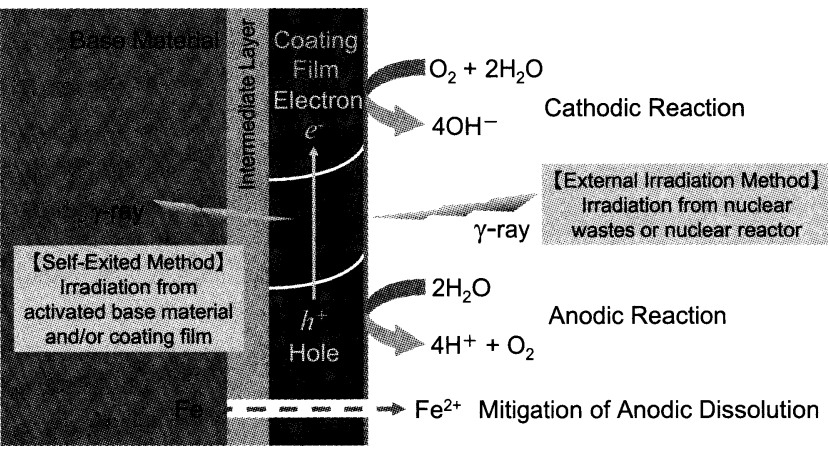

Fig. 1 Electrochemical Modeling of RISA Corrosion Protection Mechanism (in case of n-type semiconductor)

態は、表面近傍で図に示すような勾配が得られるよう になる。

この勾配の方向は皮膜の電気伝導が $\mathrm{n}$ 型半導体特性 か $\mathrm{p}$ 型半導体特性を有するかにより異なる。Fig.1 は $\mathrm{n}$ 型半導体特性を有する場合である。このような材料 に $y$ 線が照射されると、母材でコンプトン散乱などを 受けた荷電子により、皮膜の軌道電子が伝導帯に励起 され、電子が欠乏したエネルギー準位に正孔が形成さ れる。この正孔と伝導電子はそれぞれ強力な酸化力と 還元力を有する（著者らはこの現象を放射線誘起表面 活性と呼ぶ）ために、溶液との間でカソード反応とア ノード反応が進行する。各反応は溶液の種類や溶存酸 素濃度等の条件により異なる場合がある。この伝導電 子と正孔は、図の電位勾配に従って移動するため、放 射線誘起電流が測定される。放射線誘起電流の方向も 電気伝導形式によって異なる。 $\mathrm{n}$ 型半導体では電子が 酸化物被膜から金属側（図では左側）へ移動し、金属 側から半導体皮膜側への電流として測定される。これ により、母材の電位を卑化させることができる。この ときの電位が、例えば鉄のアノード溶解反応の平衡電 位よりも卑化すれば、腐食を抑制できることになる。 また、皮膜内で生成される伝導電子と正孔の移動度が ある程度大きい場合には、絶縁体に分類される広いバ ンドギャップを有する材料に対しても、上述の効果が 発現できると考えられる。

ここに提案する放射線誘起表面活性を利用した防食 法は、一種の放射線エネルギーを利用した防食法であ り、水質を調整することなく実施することができる。 また環境中に錫や亜鉛を犠牲溶解させる防食法とは異 なり、非消耗型であるという利点がある。放射線の照 射方法についても、外部から照射する方法（以後、「外 部照射法」と呼ぶ）と母材や皮膜を放射化させて自励 的に照射する方法（以後、「自励法」と呼ぶ）があり、

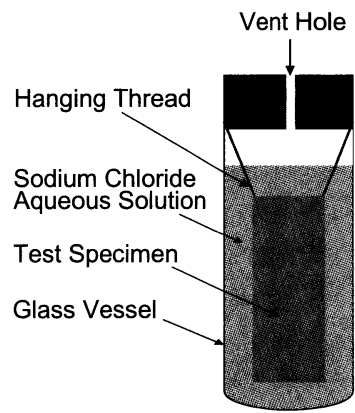

Fig. 2 Schematic Illustration of Corrosion Test Vessel

それぞれの照射方法での腐食試験結果を述べる。

\section{3. 実験手 法}

試験片の母材には純度 99.99\%の鉄、SUS304L、お よび SUS316L を用いた。試験片形状は全て幅 $20 \mathrm{~mm}$ 、 長さ $50 \mathrm{~mm}$ 、厚さ $1 \mathrm{~mm}$ とした。この表面に酸化物被 膜として酸化チタン、酸化ジルコニウム、および酸化 アルミニウムを溶射により成膜した。表面のみを試験 対象とするため、董面および端面にはエポキシ系樹脂 を塗布した。

表面の腐食様相を観察する実験では、試験片を Fig.2 に示す内径 $33 \mathrm{~mm}$ のガラス容器に入れ、腐食促進のた めに $3 \mathrm{wt} \%$ 塩化ナトリウム水溶液を $50 \mathrm{ml}$ 注入した。図 に示すように吊糸を用いて、試験片を容器中央部に鉛 直に設置した。また溶存酸素濃度は大気平衡状態とし た。試験は室温で実施した。

腐食電位およびアノード分極曲線の測定実験におい ては、幅 $58 \mathrm{~mm}$ 、長さ $145 \mathrm{~mm}$ 、深さ $145 \mathrm{~mm}$ の矩形ガ ラス容器を用いた。計測に際してはポテンショスタッ 卜 (北斗電工製 HSV-100) を用いた。試験水溶液は電 導度を与えるため $0.05 \mathrm{M}$ 硫酸ナトリウム水溶液とし、 高純度アルゴンガスを注入して脱気した。水溶液温度 は約 $30{ }^{\circ} \mathrm{C}$ に保持した。

外部照射法における $y$ 線源として、東京大学原子 力研究総合センターの ${ }^{60} \mathrm{Co}$ を用いた。照射線量率は 線源からの距離を変化させることにより、300Gy/h 〜 900Gy/h とした。本試験条件においては $\beta$ 線は自己遮 蔽により線量が無視しうるほど小さいと考えられる。

自励防食法においては、溶射後の試験片を東京大学 弥生炉の Thermal Column(TC) において 60kWh 照射 後、董面および端面にエポキシ系樹脂を塗布し、電極 面積を規定した。表面線量は鉄試験片で約 $20 \mu \mathrm{Gy} / \mathrm{h}$ 、 SUS304L 試験片で約 $150 \mu \mathrm{Gy} / \mathrm{h}$ であった。

外部照射法と自励防食法の比較試験として、紫外線 照射および暗室保管状態の試験を同様に行った。照射 光は中心波長 $352 \mathrm{~nm} 、$ 紫外線強度は UV-A において約 


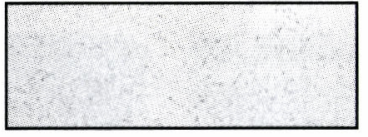

(a) Self-Exited

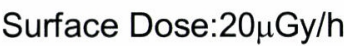

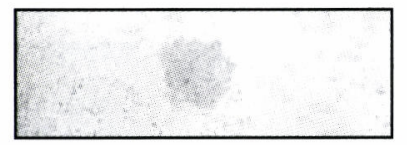

(b) UV Illumination $5 \mathrm{~mW} / \mathrm{cm}^{2}$

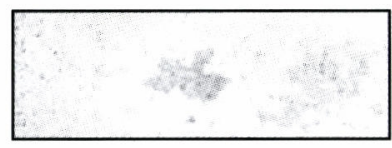

(c) Darkroom

Fig. 3 Example of General Corrosion Behavior of Activated Specimen (Alumina Coating)

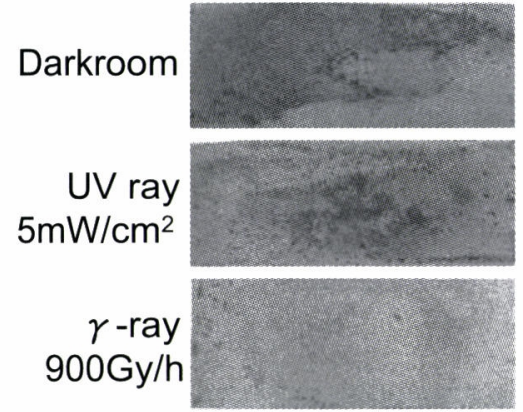

(a) $16 \mathrm{~h}$

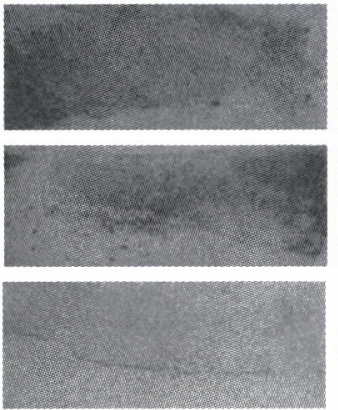

(b) $40 \mathrm{~h}$

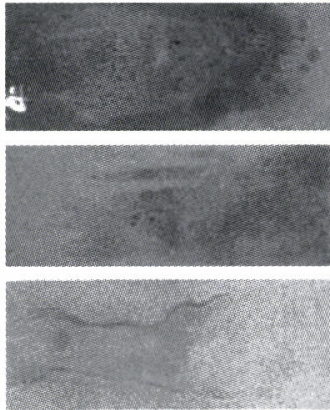

(c) $64 \mathrm{~h}$

Fig. 4 Example of General Corrosion Behavior of Irradiated Specimen in Terms of Irradiation Source and Immersion Time (Titania Coating)

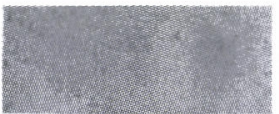

(a) $900 \mathrm{~Gy} / \mathrm{h}$

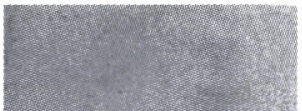

(b) $600 \mathrm{~Gy} / \mathrm{h}$

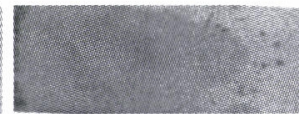

(c) $300 \mathrm{~Gy} / \mathrm{h}$

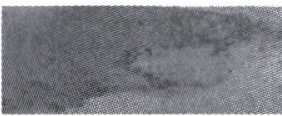

(d) $0 \mathrm{~Gy} / \mathrm{h}$

Fig. 5 General Corrosion Behavior of Irradiated Specimen in Terms of $\gamma$-ray Irradiation Dose (Titania Coating)

$5 \mathrm{~mW} / \mathrm{cm}^{2}$ である。

試験溶液中の鉄イオン濃度を求めるために、試験水 溶液の上澄みを採取し、o-フェナントロリンにより二 価の鉄イオンを発色させ、分光光度計 (日立製作所製 U-2010) を使用して定量化した。三価の鉄イオン濃度 は、アスコルビン酸により還元、発色させ、二価およ び三価鉄イオン濃度の和として計測し、前述の二価鉄 イオン濃度との差を三価鉄イオン濃度とした。その他、 実験結果の考察に必要な分析を補足的に行った。

\section{4. 腐食挙動の観察と考察}

4.1 自励法 Fig.3に酸化アルミニウムを厚さ約 $200 \mu \mathrm{m}$ 溶射した $99.99 \%$ 鉄試験片を $3 \mathrm{wt} \%$ 塩化ナトリ ウム水溶液中に $17 \mathrm{~h}$ 浸漬した後の表面状態を種々の照 射線源に対して示す。撮影は 10 分間の超音波洗浄に より表面の腐食生成物を除去し、20 分間真空乾燥し た後に行った。図より明らかなように、暗室保管の場 合、一部孔食が見られるものの、全面腐食が主であっ た。紫外線照射時も同様な全面腐食が進行しているが、
暗室の場合と比較して腐食速度は低減した。一方、放 射化試験片では、このような腐食の形跡は殆ど見られ ず、自励法により顕著な防食効果を発揮することが示 された。また、別途測定した放射化試験片のアノード 分極曲線を解析した結果、放射線誘起アノード電流が 重畳して現れることが確認された。これは $\gamma$ 線のコン プトン散乱等により、荷電子を含む軌道電子が伝導帯 に励起され、母材に到達したためと推察される。

4.2 外部照射法 Fig.4に $3 \mathrm{wt} \%$ 塩化ナトリウム 水溶液中に $16 \mathrm{~h} \sim 64 \mathrm{~h}$ 浸漬した試験片の表面状態を、照 射線源と浸漬時間に対して示す。試験片には、99.99\% の鉄試料面上に厚さ約 $220 \mu \mathrm{m}$ の酸化チタンを溶射し たものを用いた。撮影は 10 分間の超音波洗浄により 表面の腐食生成物を除去し、20 分間真空乾燥した後に 行った。図より暗室に保管した場合と紫外線を照射し た場合では同様に、一部孔食が見られるものの全面腐 食が主であった。一方、 $\gamma$ 線を照射した場合には、こ のような腐食の形跡は殆ど見受けられなかった。Fig.4 に示すように、溶液浸漬時間を $40 \mathrm{~h}, 64 \mathrm{~h}$ とした実験を 
行った結果、暗室の場合には腐食が更に進行したが、 $\gamma$ 線照射の場合は腐食の進行が遅いことが確認された。 これらの結果から、外部照射法においても顕著な防食 効果を発揮することが示された。

Fig.5 に $y$ 線照射線量率の影響を示す。試験片には 上記と同様のものを用い、 $3 \mathrm{wt} \%$ 塩化ナトリウム水溶 液中に $16 \mathrm{~h}$ 浸漬した。線量率の低下に伴い、孔食と全 面腐食が明膫に見られた。このことからも線量率を増 大させることにより、一層高い防食効果が期待できる ことが分かった。また、酸化チタン以外にも、酸化ジ ルコニウムと酸化アルミニウムに対しても同様な試験 を行い、 $\gamma$ 線照射により高い防食特性が得られること が判明した。

前述の浸漬腐食試験後の酸化チタン溶射皮膜の断 面を SEM-EDX を用いて分析した。試験片は $3 \mathrm{wt} \%$ 塩 化ナトリウム水溶液中に $16 \mathrm{~h}$ 浸漬したものを用いた。 Fig.6に、 $y$ 線を $900 \mathrm{~Gy} / \mathrm{h}$ 照射した試験片について腐 食が最も進行した場所の断面方向の (a)SEM 画像、(b) 鉄元素分布、(c) チタン元素分布、(d) 酸素元素分布を 示す。Fig.6(b) および (c) から分かるように、四中下方 1/3 の領域は母材の鉄である。それより上部に酸化物 被膜が形成されており、図 (b) や (d) で見られるよう に、母材の上部すなわち外表面には軽微な腐食が進行 していることが分かる。

Fig.7 に、暗室に保管した試験片の SEM 画像と鉄、 チタンおよび酸素の元素分布を示す。 $y$ 線を照射した 試験片と比較して、腐食が深く進行していることが分 かる。

Fig.8 に、前述の $\gamma$ 線照射試験片の溶射皮膜断面の 拡大図を示す。SEM 画像で分かるように溶射皮膜はそ の成膜特性から空孔が多数見受けられる。その大きさ と形状も様々であるが、Fig.8(c) より、左下付近の空 孔は大きく、その場所では Fig.8(b) に示されるように 鉄元素が存在する。暗室に扔ける溶射皮膜についても 空孔の数や大きさも同程度見受けられた。すなわち、 溶射皮膜内には鉄の溶解経路が多数確認された。しか しながら $\gamma$ 線照射試験片では、その経路における鉄濃 度が著しく低いことから、腐食電位が低下することに より溶射皮膜と母材界面からの鉄の溶解が抑制された ものと考えられる。

\section{5. 電気化学的試験結果と考察}

Fig.9 に酸化ジルコニウム皮膜付き SUS304L 試駼片 の暗室保管状態における腐食電位の経時変化を示す。 この SUS304L 試験片には中間層として厚さ $100 \mu \mathrm{m}$ の $\mathrm{CoCr}$ が成膜されており、さらに酸化ジルコニウムを厚

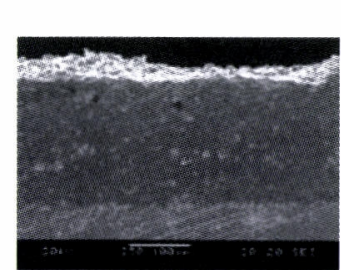

(a) SEM micrograph

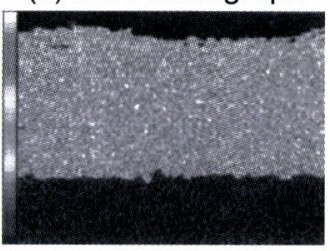

(c) $\mathrm{Ti}$

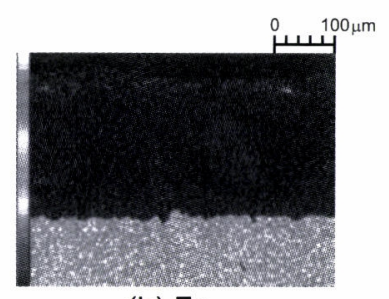

(b) $\mathrm{Fe}$

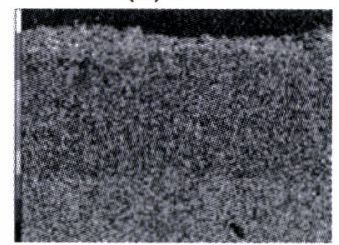

(d) $\mathrm{O}$
Fig. 6 SEM-EDX Images across the Titanium Oxide Layer after Corrosion Test ( $\gamma$-ray Irradiation)

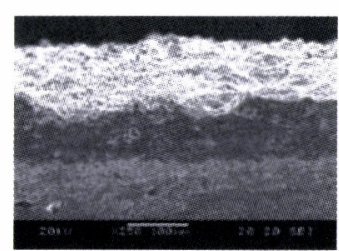

(a) SEM micrograph

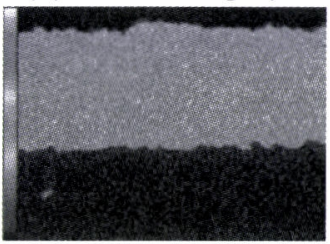

(c) $\mathrm{Ti}$

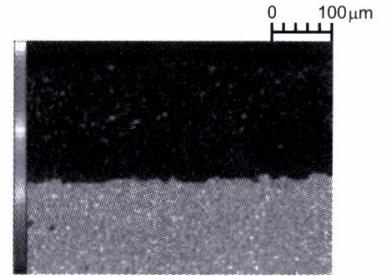

(b) $\mathrm{Fe}$

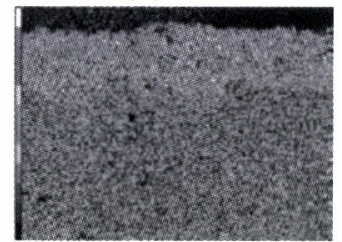

(d) $\mathrm{O}$
Fig. 7 SEM-EDX Images across the Titanium Oxide Layer after Corrosion Test (Dark Room)

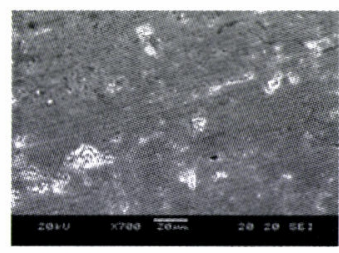

(a) SEM micrograph

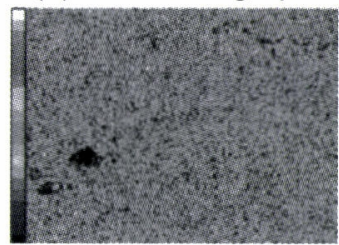

(c) $\mathrm{Ti}$ (b) $\mathrm{Fe}$

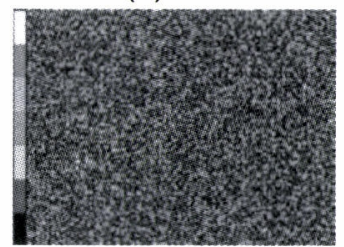

(d) $\mathrm{O}$

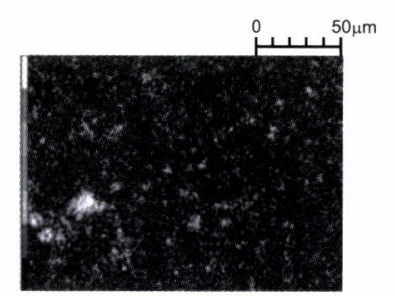

Fig. 8 Magnified SEM-EDX Images across the Titanium Oxide Layer after Corrosion Test ( $\gamma$-ray Irradiation) 
さ $500 \mu \mathrm{m}$ 溶射した。溶液は $0.05 \mathrm{~mol} / 1$ の硫酸ナトリウ ム水溶液である。測定前に 30 分間アルゴンガス通気 による脱気を行った。図より腐食電位は計測開始後や や卑方向に移行し、7h 時間以降は約 $30 \mathrm{mV} v$ s. SSE(対 飽和銀/塩化銀電極電位) で安定することが分かる。

Fig.10 に前述の酸化ジルコニウム皮膜付き SUS304L 試験片に ${ }^{60} \mathrm{Co}$ からの $y$ 線を $600 \mathrm{~Gy} / \mathrm{h}$ 照射した場合の 腐食電位の経時変化を示す。図より腐食電位は計測開 始後卑方向に移行し、16h 時間以降は安定した。そこ で本研究では、計測開始後 $23 \mathrm{~h}$ 時間経過以降の電位を 腐食電位として試験結果を整理することとした。

Fig.11 および 12 に、それぞれ SUS304L および SUS316L 試験片の腐食電位を $\mathrm{CoCr}$ 中間層および酸 化ジルコニウムの厚さをパラメータとして示す。試験 条件は Fig.9,10 と同一である。これらの図より母材の SUS304L と SUS316L との違いによる腐食電位の差異 は小さいことが分かる。中間層がない場合には腐食電 位は $-90 \mathrm{mV} \sim-300 \mathrm{mV} v \mathrm{vs} . \mathrm{SSE}$ まで卑化するのに対 し、SUS と溶射皮膜の間に CoCr 中間層を設けた場合、 腐食電位は約 $-600 \mathrm{mV} v s . \mathrm{SSE}$ まで杽化した。これは、 中間層が溶射皮膜と母材との間の電気的コンダクタン スを良好にするためと考えられ、 $20 \mu \mathrm{m}$ 程度の厚さが あれば十分であると考えられる。また、溶射皮膜の厚 さが腐食電位に与える影響は本試験範囲の $300 \mu \mathrm{m}$ $900 \mu \mathrm{m}$ では小さいことが分かった。

Ohko et al. ${ }^{15)}$ は、SUS304 上にゾルゲル法により酸 化チタンを成膜し、 $3 \mathrm{wt} \%$ 塩化ナトリウム水溶液 $(\mathrm{pH} 5)$ 中で紫外線を $25 \mathrm{~mW} / \mathrm{cm}^{2}$ 照射したときの腐食電位が 約 $-410 \mathrm{mV} v$ s. SSE であることを報告している。著者 らの知る限り、従来ステンレス鋼の腐食電位がこの值 より卑化した実験結果は報告されていない。以上によ り、中間層 $\mathrm{CoCr}$ を設けた酸化ジルコニウム溶射膜に $y$ 線を照射することにより、ステンレス鋼母材の腐食 電位を約 $-600 \mathrm{mV} v s . \mathrm{SSE}$ まで卑化できる、顕著な腐 食軽減効果が期待できることが確認された。

\section{6. 結 論}

放射線誘起表面活性 (RISA) を活用した防食法の一 環として、半導体特性を有する酸化物被膜に放射線を 照射し、母材の耐食性を把握する実証試験を行い、以 下の結論を得た。

（1）酸化ジルコニウムなどの半導体特性を有する酸 化物被膜に $y$ 線を照射することにより、励起電子 が皮膜に接する金属に移行して電位を卑化させる 放射線誘起表面活性 (RISA) 防食現象を見いだし

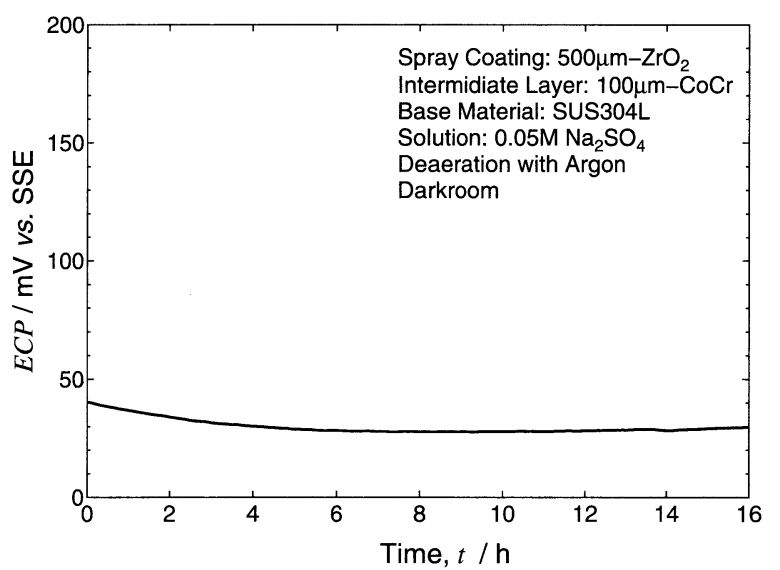

Fig. 9 Transients of Corrosion Potential with Time

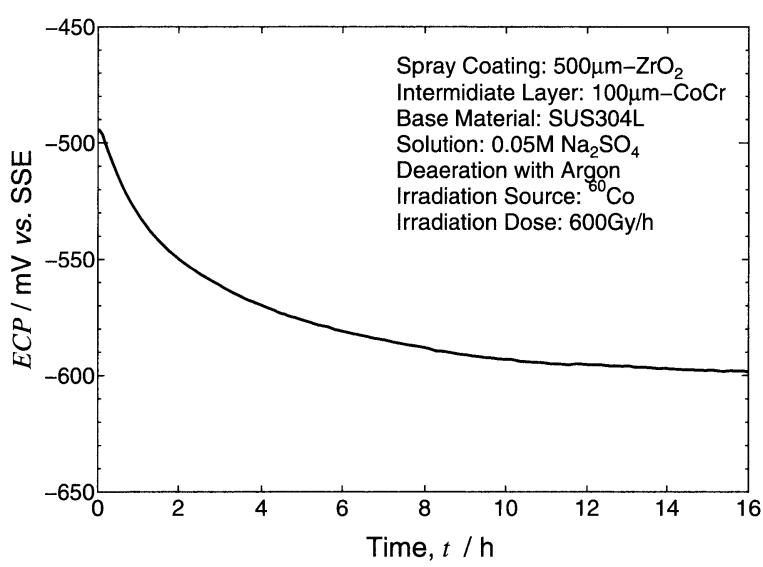

Fig. 10 Transients of Corrosion Potential with Time under $y$-ray Irradiation

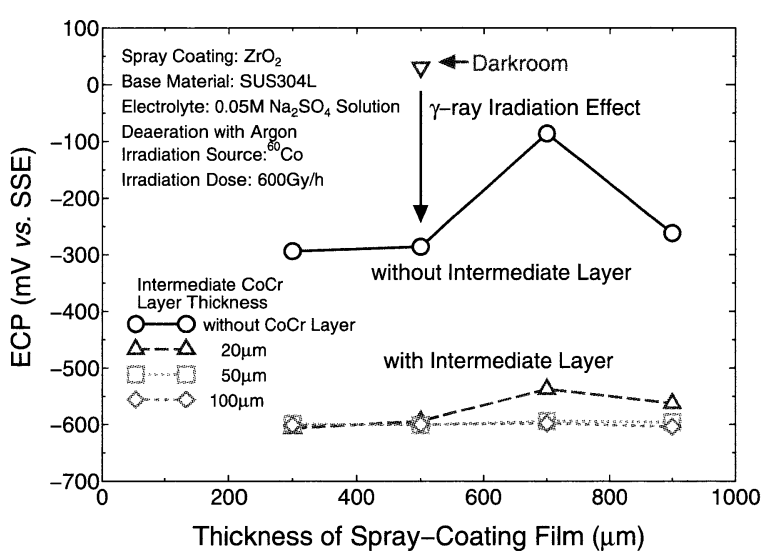

Fig. 11 Summary of Corrosion Potential of SUS304L in Terms of Various Coating Conditions 


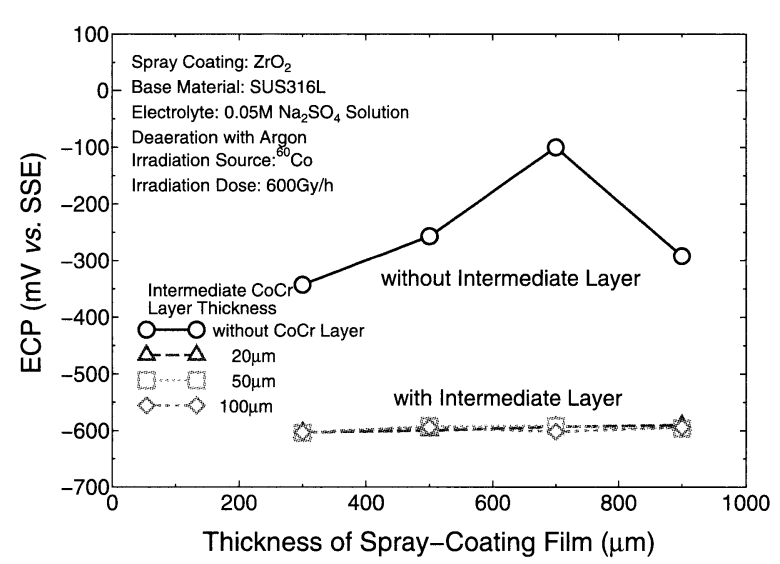

Fig. 12 Summary of Corrosion Potential of SUS316L in Terms of Various Coating Conditions

た。この現象を利用して、外部から $\gamma$ 線を供給し たり、皮膜や金属を放射化させて自励的に $y$ 線を 供給させることにより、金属の腐食を抑制する二 つの手法を考案した。

（2）酸化ジルコニウム、酸化チタン、および酸化アル ミニウムを鉄板に溶射し、3wt \%塩化ナトリウム 水溶液中に $16 \mathrm{~h} \sim 64 \mathrm{~h}$ 浸漬する耐食性試験を行っ た。比較試験として実施した暗室保管および紫外 線照射試験片では全面腐食が観察されたが、放射 化させた試験片および $y$ 線照射試験片では腐食の 形跡は殆ど見られなかった。全面腐食試験後の酸 化チタン溶射皮膜の断面を SEM-EDXを用いて分 析した結果、溶射皮膜内に鉄の溶解経路が確認さ れた。また、放射化試験片では、その経路におけ る鉄濃度が著しく低いことが判明した。

(3) 酸化ジルコニウムを溶射した SUS304L および SUS316L 試験片に $\gamma$ 線を照射することにより、腐 食電位が $-90 \mathrm{mV} \sim-300 \mathrm{mV} v \mathrm{vs.SSE}$ まで卑化す ることが分かった。また、ステンレス鋼と溶射皮 膜との間に $\mathrm{CoCr}$ 中間層を設けることで、さらに $-600 \mathrm{mV}$ まで杽化し、多くの金属の応力腐食割れ や腐食防止に対して有用であることを確認した。

\section{謝辞}

本研究を遂行するに当たり、(株) 電力テクノシステ ムズ白鳥義行氏、東京海洋大学波津久 達也助教授、 杉本泰氏、中村大輔氏、東京大学広石大介氏、池
田秀松氏、今井康之氏、(株) コベルコ科研 福留 和 幸 氏、神戸製鋼所藤沢匡介氏、下条 純氏、(財) 電力 中央研究所常磐井守泰氏、河村浩孝氏、松村哲夫 氏の協力を得た。ここに記し、感謝の意を表します。

\section{文献}

（1）柴田俊夫,「ステンレス鋼不動態研究の流れ」, 材 料と環境 2004 講演大会予稿集, No. C-108 (2004).

(2) 藤本慎司, 土谷博昭, $「 \mathrm{Fe}-18 \mathrm{Cr}$ 合金に生成する不 動態皮膜の電子構造」, 材料と環境 2004 講演大 会予稿集, No. C-107 (2004).

(3) 藤本慎司，「腐食に及ぼす光の作用と紫外線によ る不動態皮膜改質」, 材料と環境, 51 (2002), 453457.

(4) 藤本慎司, 河内繁希, 柴田俊夫, 「硫酸水溶液中 での $\mathrm{Fe}-18 \mathrm{Cr}$ 合金に生成する不動態皮膜の紫外 線照射による改質」, 日本金属学会誌, 63 (1999), 375-382.

（5）藤本慎司，「鉄系金属に生成する不動態皮膜の半導 体構造と光誘起改質」, 金属, 73, 8 (2003), 14-20.

(6) 杉本克久,「不動態-最近 20 年間の研究動向」, 材 料と環境, 53 (2004), 159-161.

（7）杉本克久，「ステンレス鋼の不動態皮膜の防食機 能と破壊機能」, 金属, 73, 8 (2003), 4-13.

（8）妹川透, 藤澤龍太郎, 須田新, 过川茂男, 「腐食に及 ぼす光の作用と紫外線による不動態皮膜改質」, 材料と環境, 43 (1994), 482-486.

(9) Akashi, M., Iso-o, H., Hirano, K., Kubota, N., Fukuda, T. and Ayabe, M., "photoelectrochemical protection of stainless alloys from the stresscorrosion cracking in BWR primary coolant environment", 7th International Symposium on Environmental Degradation of Materials in Nuclear Power Systems - Water Reactors, Vol. Colorado (1995).

(10) Fukaya, Y., Akashi, M., Yotsuyanagi, T., Takagi, J., Sanbongi, M., Takamori, K. and Suzuki, S., "photoelectrochemical protection of stainless alloys in BWR primary coolant environment", Proc.10th Int Symp. Environmental Degradation of Materials in Nuclear Power Systems - Water Reactors, Vol. Lake Tahoe, Nevada, National Association of Corrosion Engineers (2001). 
(11) 古谷正裕, 賞雅寛而, 岡本孝司, 「放射線誘起表面 活性を用いた防食」,第 67 回マリンエンジニア リング学術講演会講演論文集, No. B15 (2002).

(12) Takamasa, T., Hazuku, T., Tamura, N., Mishima, K., Okamoto, K. and Furuya, M., "effect of surface wettability caused by radiation induced surface activation on leidenfrost condition", 10th Int. Topical Meeting on Nuclear Reactor Thermal Hydraulics, NURETH-10, Vol. Seoul, Korea (2003).

(13) Takamasa, T., Hazuku, H., Mishima, K., Okamoto, K., Imai, Y. and Furuya, M., "surface wettability caused by radiation induced surface activation on Leidenfrost condition", Thermal Sci. Enging., 12, 1 (2004), 35-40.

(14) Takamasa, T., Hazuku, T., Okamoto, K., Mishima, K. and Furuya, M., "radiation induced surface activation on Leidenfrost and quenching phenomena", hermal and Fluid Science, 29 (2005), 267-274.

(15) Ohko, Y., Saitoh, S., Tatsuma, T. and Fujishima, A., "photoelectrochemical anticorrosion and self-cleaning effects of a $\mathrm{TiO}_{2}$ coating for type 304 stainless steel", J. Electrochemical Society, 148, 1 (2001), B24-B28. 